DJS Vol. 44 (1) (2022) - pp. 81-98 ISSN: 1012-5965

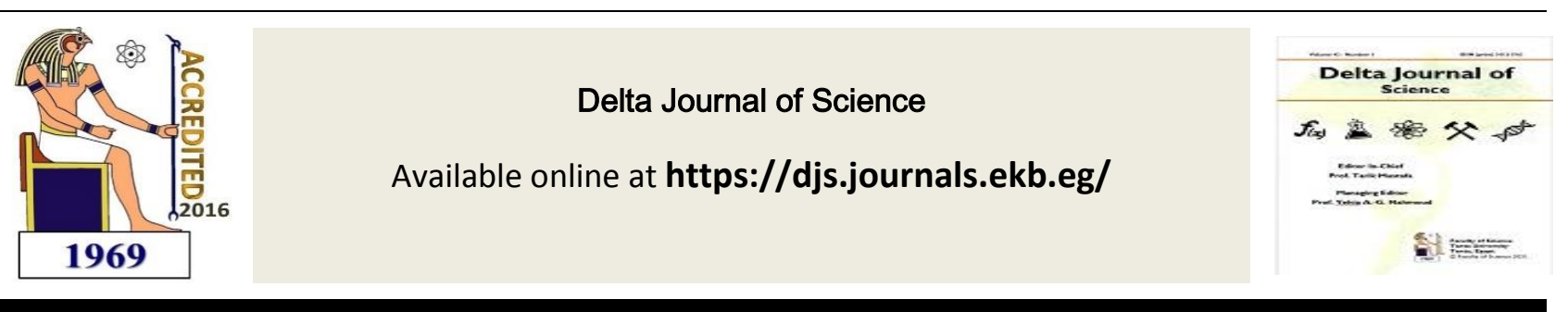

Research Article

GEOLOGY

\title{
Palynological Studies on the Upper Cretaceous Wata and Matulla Formations in Bakr Oil Field, Gulf of Suez, Egypt
}

\author{
Somia Said $^{1,2}$, Mahmoud Faris ${ }^{2}$, Abdel Fattah Zalat ${ }^{2}$, Ali Soliman ${ }^{2}$ \\ 1 General Petroleum Company, Exploration Department, Nasr City, 11759, Egypt \\ 2 Geology Department, Faculty of Science, Tanta University, Tanta 31527, Egypt \\ Corresponding author: Somia Said \\ e-mail:somia_sayed@science.tanta.edu..eg \\ Received: 4/1/2022 \\ Accepted: $30 / 1 / 2022$

\section{KEY WORD/S/} \\ Miospores, \\ Dinoflagellate \\ cysts, Turonian, \\ Coniacian, \\ Santonian, Wata \\ Formation, Matulla \\ Formation, Bakr \\ Oil Field, Gulf of \\ Suez

\section{ABSTRACT} \\ Palynological investigation of the subsurface Upper Cretaceous \\ (Turonian-Santonian) Wata and Matulla formations in three wells \\ drilled in the Bakr oilfield, Gulf of Suez area is presented. 147 species \\ of palynomorphs (spores, pollen dinoflagellate cysts and prasinophytes \\ green algae) are identified. A Turonian-Santonian age is suggested \\ based on the occurrences of many diagnostic taxa such as Liliacidites \\ farafraensis, Droseridites senonicus, Ephedripites ambiguus, \\ Isabelidinium cooksoniae, Isabelidinium glabrum, Odontochitina \\ porifera, Odontochitina costata, Canningia reticulata and Trichodinium \\ castanea. The paleoenvironmental reconstruction of the studied interval \\ indicates the carbonate-dominated Wata Formation was deposited \\ during the Turonian transgressive condition and the Matulla Formation \\ which is consist of clastic-dominate deposited during the Coniacian- \\ Santonian regressive phase. The presence of Palm Province pollen such \\ as Arecipites, Retimonocolpites and Longapertites associated with the \\ pteridophytes spores refer to a tropical humid climate in the area of \\ deposition. The abundance of green algae Pediastrum and occurrences \\ of Crybelosporites water fern indicate discharge of freshwater into the \\ basin.
}




\section{Introduction}

Gulf of Suez is one of the most intensively faulted areas, that is approximately 19-32 Km wide and $319 \mathrm{Km}$ long from its head at city of Suez to its south at Ras Mohammed near its junction with the Red Sea, with average water depth 55-100 m (Young et al., 2000).

Bakr oil field is located on the western side of the Gulf of Suez, about $10 \mathrm{Kms}$ north of Gharib oil field, and about $40 \mathrm{Kms}$ north of Ras Shukher Field (Fig.1). Bakr oil field is pre-Miocene fault block that has northwestsoutheast trend that is dissected by transverse cross faulting into two blocks Bakr north and Bakr south. Since the discovery of Ras Gharib oil field in 1938, which is based on gravity data, that drawn the attention to Bakr area. Successive wells were drilled on the basis of seismic, magnetic, and gravity data (GPC internal report). The Upper Cretaceous sections which consist of chalk, marls, limestone, clay and sandstone are overlying the Paleozoic Nubia section.

Several micropalaeontological and stratigraphical studies of the Upper Cretaceous (including surface and subsurface) based upon foraminiferal and nannofossils have been done in the Gulf of Suez area (e. g. Said and Kenawy, 1957; Bold, 1964; Hataba and Ammar, 1990; Mandur and Baioumi, 2009; Mousa et al., 2011; Boukhary et al., 2014; Farouk, 2015). Few studies dealt with the Upper Cretaceous palynology, mainly palynofacies and organic geochemistry analysis have been published (EI Diasty $\boldsymbol{e t}$ al., 2014; El Diasty et al., 2017; Sultan et al., 1986).

The current work focuses on the palynological characteristics of the Upper
Cretaceous (Turonian-Santonian) deposits in the Gulf of Suez aims to:

(1) Reconstruct palynostratigraphic framework and age assignment and

(2) Throw some light on the depositional environment of the studied formations based on terrestrial and marine palynomorphs.

\section{Geological setting and ithostratigraphy}

In the Gulf of Suez area, Lower Cretaceous sediments hosts more than one reservoir such as Cenomanian clastic deposits (Raha Formation) and Upper Cretaceous clastics deposits (Wata and Matulla formations). In our study we concerned with two important reservoirs; the Turonian sand and limestones of the Wata Formation and the Santonian sands of the Matulla Formation.

Matulla Formation is introduced by Ghorab (1961) for the ConiacianSantonian section that ranges between 100 and $159 \mathrm{~m}$ in the studied area. It is conformably overlies the Wata Formation and underlies the Campanian Brown Limestone. It is a sandstone-dominated stratigraphic unit, interbedded with limestone and shale beds. The sandstones are brown to grey, moderately hard, veryfine to fine-grained and calcareous. The Matulla Formation is subdivided based on lithological and electrical characters into five subunits (M1-M6). The Wata Formation (Ghorab, 1961) overlies the Raha and underlies the Matulla formations respectively, covers the interval between 90 and $120 \mathrm{~m}$ thick in the study area. This term describes the carbonate section of a transgressive phase prevailed at the end of the Turonian age. It is mostly built up of white to light brown, moderately hard, 
glauconitic and pyritic limestone beds. These limestone beds are characterized by low gamma-ray, and neutron readings, while they show high resistivity and density readings, and it can be subdivided into four units (W-1 to W-4) according to lithological and electric characters (Figs. 24).

\section{Material and methods}

The ditch cutting samples recovered from Bakr-12, Bakr-13, and Bakr-17 wells were processed using standard palynological technique of (Wood $\boldsymbol{e t}$ al., 1996; Soliman, 2012). 10-15 gm of each sample were treated using a porcelain mortar to facilitate subsequent chemical reaction. Firstly, carbonates were removed by reaction with $\mathrm{HCl}(10 \%)$ for approximately 24 hours until effervescence stopped. Samples were washed several times with distilled water and then added 30-50 ml Conc. HF (40\%) for silicate removal, then residue was washed by distilled water. The neutralized residue was passed through a $125 \mu \mathrm{m}$ brass sieve and 10 $\mu \mathrm{m}$ nylon mesh to separate the organic matter from any remaining unwanted inorganic material. No oxidation was carried out in order to avoid damage to the palynomorphs. At least one slide from each sample is scanned. The miospores, pollen grains and dinoflagellate cysts are identified to species level whenever possible. Some diagnostic taxa are photographed with Leica Microscope equipped with HD camera, housed in Geology Department, Faculty of Science, Tanta University in the collection of the Botanical microfossils and Paleoecology Lab.

\section{Palynological results}

147 species of palynomorphs are identified from the Wata and Matulla successions encountered in the studied wells. The identified taxa in the present study are divided into spores, pollen grains, dinoflagellate cysts and prasinophytes green algae according to their affinities. The identified diagnostic taxa are presented in range charts (Figs. 2-4) and some stratigraphically important forms are illustrated in (Figs 5-8). For taxa authorship references see (Ravn, 1998) for miospores and

(http://dinoflaj.smu.ca/dinoflaj3/index.php/ Main_Page) for dinoflagellate cysts.

The encountered spores are mostly characteristic of the Upper Cretaceous, however some of them are of long stratigraphic ranges. Among the identified spores we can list the widely known taxa such as Biretisporites boltenhagenii; $B$. potoniaei; Crybelosporites aegypticus; $C$. pannuceus; Foveotriletes subtriangularis; Gabonisporis vigourouxii; Microreticulatisporites sacalii; $\quad M$. uniformis and Zlivisporis blanensis. Some megaspores are also identified such as Ariadnaesporites caperatus; $A$. longiprocessum; A. rugulatus and $A$. spinocaperatus.

The diagnostic gymnosperm pollen taxa are represented by Classopollis brasiliensis $C$. jardinei; Ephedripites ambiguus; $E$. brasiliensis; $\quad$ E. multicostatus; Inaperturopollenites undulates and Steevesipollenites binodosus. While the angiosperm pollens are represented by Arecipites microfoveolatus; A. microreticulatus; A. punctatus; Droseridites baculatus; $D$. senonicus; Foveotricolpites gigantoreticulatus; $F$. giganteus; Liliacidites farafraensis and Tricolpites crassimurus.

The dinoflagellate cysts are more diversified and of good preservation state. Many Upper Cretaceous taxa are identified from the studied successions and many of 
them have a stratigraphic value such as Canningia senonica; Chatangiella chetiensis; $C$. ditissima; Circulodinium distinctum; Cometodinium obscurum; Coronifera oceanica; Cyclonephelium filoreticulatum; C. membraniphorum; Dinogymnium acuminatum; D. denticulatum; D. vozzhennikovae; Isabelidinium; I. belfastense; I. cooksoniae; I. glabrum; Odontochitina costata; $O$. porifera; Palaeohystrichophora infusorioides; Senoniasphaera rotundata rotundata; Spinidinium echinoideum and Trichodinium castanea.

\section{Age assignment}

The three studied sedimentary successions in Bakr oil field are attributed to the Late Cretaceous according to their identified palynomorphs. The findings are correlated with previous studies in both Gulf of Suez and Western Desert of Egypt in addition to other studies in Africa, Europe, South and North America.

\subsection{Santonian}

It comprises the intervals extending from 2560 to $2657 \mathrm{ft}$ in Bakr-13, from 2460 to $2520 \mathrm{ft}$ in Bakr-17, and it is missed in Bakr-12 for probably structure/tectonic activity. These intervals are dated as Santonian age according to first downhole occurrence (FDO) of Odontochitina poriferalO. costata Cookson (1956). According to Helby et al., (1987) $O$. porifera exists in post- Coniacian sediments based on the age of the assemblage. Cookson (1956) described $O$. porifera from the "Senonian" of Australia. It is recorded from eastern Greenland (Nøhr-Hansen, 2012) to East Antarctica (Macphail and Truswell, 2004). The first downhole occurrences of $O$. porifera indicate the start of mid Santonian that supposed by many authors (e.g. Williams and Brideaux, 1975; Bujak and Williams, 1978; Williams and Bujak, 1985; Williams et al. 1993; Schrank and Ibrahim, 1995). According to Williams et al., (2004) the first appearance datum (FAD) of O. porifera is dated at $84.12 \mathrm{Ma}$ (Santonin) in the Northern Hemisphere. Nøhr-Hansen et al., (2019) put the first occurrence of $O$. porifera at the base of the Santonian in their zone Chatangiella spinosa (middle Coniacian to middle Santonian). Pearce et al., (2020) assumed the first occurrence of $O$. porifera is the early Santonian and the last occurrence lies in the Campanian.

In Egypt, O. porifera is considered as a characteristic Coniacian-Santonian marker (Schrank and Ibrahim, 1995; Abdel-Kireem et al., 1996;El-Soughier et al., 2013 and El Diasty et al., 2014). Deaf et al., (2014) supposed a Coniacian-early Campanian age including Tethys ranges.

The FDO of Canningia reticulata and $C$. senonica is encountered within this zone at B-13 and B-17. C. reticulata has a stratigraphic range from the Late Jurassic (Berthou and Leereveld, 1990) through the Santonian (Robaszynski et al., 1980). C. senonica is first described by Clarke and Verdier (1967) from the Santonian of the Isle of Wight, UK and it has a stratigraphic range from the Cenomanian (Srivastava, 1992) to the lower Campanian (Foucher, 1979). The total range of $C$. senonica defined the early Santonian- (PZ-5) zone of Deaf et al., (2014) at the Abu Tunis-1x borehole, North Western Desert Egypt.

The co-occurrences of Liliacidites, Arecipites spp., $F$. giganteus or $F$. gigantoreticulatus are common ConiacianSantonian angiosperm pollen grains worldwide. In Egypt, they indicate a relatively similar age. Liliacidites 
farafraensis was described from the ElHefhuf Formation (Late Turonian Santonian) by Ibrahim and Abdel-Kireem (1997). It is recorded from Turonian- lower Santonian of Abu Roash Formation as Liliacidites sp. (Schrank and Ibrahim, 1995), and Coniacian-Santonian (Mahmoud, 2003) of north Western Desert. L. farafraensis is dated as of Santonian age as indicated by (Ibrahim et al., 2009). They defined the "Liliacidites spp.Zilivisporis blanensis - Ariadnaesporites longiprocessum" Assemblage Zone. The Liliacidites sp. (cf. farafraensis) is recorded from the Matulla Formation in the Belayim oilfield (central Gulf of Suez) and in the West Esh El Mellaha area (SW Gulf of Suez) and this species belongs to Coniacian-Santonian age (El Diasty et al., 2014).

\subsection{Coniacian}

It comprises the intervals extending from 2561 to $2763 \mathrm{ft}$ in Bakr-12, from 2657 to $2866 \mathrm{ft}$ in Bakr-13, and from 2520 to $2700 \mathrm{ft}$ in Bakr- 17. These intervals are dated as Coniacian age according to first downhole occurrence (FDO) of Isabelidinium complex (I. glabrum, I. cooksonia and I. belfastense and the lower boundary is defined by the FDO of $T$. castanea.

I. glabrum is a Turonian-Coniacian marker species in the uppermost part of the $P$. infusorioides Zone and the lowermost part of the Conosphaeridium striatoconus Zone of the Australian Mesozoic Palynological Scheme of Helby et al., (1987). Riding and Crame (2002) suggested a Coniacian age for a single sample from Hidden Lake Formation of the Gustav Group, James Ross Basin, Antarctica based on the occurrence of $I$. glabrum. I. acuminatum was recorded from the foraminiferal constrained ConiacianSantonian of Algeria (Foucher et al., 1994).

Nøhr-Hansen (1996) defined $S$. echinoideum interval zone of late Coniacian age according to its first occurrence in West Greenland. Schioler and Wilson (1998) defined an acme of S. echinoideum in the middle part of late Coniacian - early Santonian C. abbreviatum interval zone from Ben More and Kekerengu sections, New Zealand. In the northern Hemisphere, Williams et al., (2004) reported that the age of the last appearance of $S$. echinoideum to be late Coniacian, also recorded from upper Coniacian lower Berezovo subformation in northern Siberia (Lebedeva, 2006). Prince et al. (2008) defined Spinidinium echinoideum from upper Coniacian Chalk in the Kingsdown Cliffs of east Dover.

D. senonicus is a global diagnostic species in the Late Cretaceous. In Egypt it was recorded from the Turonian-lower Santonian of Gulf of Suez (Sultan et al., 1986); Turonian-lower Santonian (Schrank \& Ibrahim, 1995); Coniacian (Ibrahim, 1996); late Turonian-Santonian of Farafra Oasis (Ibrahim \& Abdel Kireem, 1997); late Turonian- Coniacian (Ibrahim et al., 2009; El Beialy et al., 2010; El Diasty et al., 2014) and Coniacian-Santonian (Ied and Tahoun, 2018).

\subsection{Turonian}

It comprises the intervals extending from 2763 to $3200 \mathrm{ft}$ in Bakr-12, from 2866 to $3200 \mathrm{ft}$ in Bakr-13, and from 2700 to $3060 \mathrm{ft}$ in Bakr- 17. This interval is defined by FDO of E. ambiguus and $E$. multicostatus and FDO of T. castanea to the end of the studied interval.

In Egypt, E. ambiguus (Equisetosporites ambiguus) was recorded from the late Cenomanian-Turonian 
(Ibrahim, 1996; Aboul Ela et al., 2019) and from early- late Turonian of Eastern Desert (Tahoun et al., 2017). It is also encountered from the Cenomanian Turonian of Gabon (Boltenhagen, 1980), and the late Turonian of Canada (Sweet and McIntyre, 1988). On the other hand, $E$. multicostatus is recorded from the early Turonian of Eastern Desert (Tahoun et al., 2017); middle Albian - early Turonian of north Western Desert (Aboul Ela et al., 2019). In Nigeria, it is recorded from the Turonian through the Maastrichtian by (Lawal and Moullade, 1986).

In Egypt, $T$. castanea is a Turonian diagnostic taxon. It was recorded from Turonian (Schrank and Ibrahim, 1995); middle late Turonian (Aboul Ela et al., 2019), late Cenomanian - Santonian (Ibrahim et al., 2009), late Albian - early Santonian (Deaf et al., 2014), Turonian (Aboul Ela et al., 2013), early Cenomanian - Santonian (Ibrahim et al., 2020) of north Western Desert, and from the early Turonian -Coniacian of Eastern Desert (Tahoun et al., 2017).

\section{Depositional environment}

Our studied stratigraphic succession in Bakr -12, 13 and 17 wells, Gulf of Suez area, begins with carbonate-dominated Wata Formation that deposited during Turonian transgressive marine condition which prevailed over a larger part of north Egypt (Kerdany and Cherif, 1990). Limestone beds dominated the lower and upper subunits (Wata 1 and Wata 4 subunits), while sandstone interbedded with shale and mudstone beds are common in Wata 2 and Wata 3 subunits. The palynomorphs that recovered from Turonian Wata Formation are dominated by dinoflagellate cysts, where high dinoflagellate cyst concentrations have been found to show offshore increase to the continental slope, where with increased water depth they begin to decline (Balch $\boldsymbol{e t}$ al., 1983; De Vernal and Giroux, 1991). Occurrences of fresh water green algae especially Scenedesmus bifidus with Pediastrum boryanum in marine strata occur as part of an allochthonous association that brought by rivers and streams from freshwater catchment area (Brenac and Richards, 1996).

The Coniacian-Santonian Matulla Formation was deposited during Conicain Santonian regressive phase (G.P.C, 2014). It is composed of sandstone, shale and limestone intercalations. The identified palynological assemblage from Matulla Formation includes an alternated spores, pollen grains and dinoflagellate cysts, may suggest shallow marine environment and may confirm deposition under marginal conditions.

\section{Conclusions}

The present study challenge is to provide a unifying subdivision of the Upper Cretaceous Wata and Matulla formations units in the Gulf of Suez based palynological results. The palynological examination of the studied samples from three wells (Bakr- 12, Bakr- 13, Bakr- 17 wells), led to identify 147 species of spores, pollen grains, and dinoflagellate cysts. These allowed recognition of many marker taxa such as $\mathrm{O}$. porifera / $O$. costata, Droseridites senonicus, L. farafraensis and Arecipites spp. (Santonian); Isabelidinium spp. (Coniacian); E. ambiguus C. jardinei $T$. castanea (Turonian). The identified assemblages may suggest shallow marine environment and may confirm deposition under marginal conditions. A fresh-water inputs to area of deposition is indicated by the abundance of the green algae Pediastrum. 


\section{Acknowledgements}

The authors are greatly appreciated to Egyptian General Petroleum Corporation (EGPC) and General Petroleum Company (GPC) for samples, data, well logs and giving us the data and permission for publishing this paper.

\section{References}

Abdel-Kireem, M., Schrank, E., Samir, A.M., Ibrahim, M., 1996. Cretaceous palaeoecology, palaeogeography and palaeoclimatology of the northern Western Desert, Egypt. Journal of African Earth Sciences 22: 93-112.

Aboul Ela, N., Tahoun, S., El Barkooky, A., Abdo, A., 2013. Palynostratigraphy of the subsurface Albian-Turonian sequence in Abu Gharadig basin, Western Desert, Egypt, 2nd Symposium on the Geological Resources in the Tethys Realm. Aswan: Aswan University, pp. 149-180.

Aboul Ela, N., Tahoun, S., Raafat, A., 2019. The Cretaceous (BarremianMaastrichtian) palynostratigraphy and palynofacies of the Drazia-1 well, north Egypt. Palynology 44: 94-113.

Balch, W., Reid, P., Surrey-Gent, S., 1983. Spatial and temporal variability of dinoflagellate cyst abundance in a tidal estuary. Canadian Journal of Fisheries and Aquatic Sciences 40: 244-261.

Berthou, P., Leereveld, H., 1990. Stratigraphic implications of palynological studies on Berriasian to Albian deposits from western and southern Portugal. . Review of Palaeobotany and Palynology, 66: 313-334.

Bold, W. 1964. Ostracoden Aus Der Oberkreide Von Abu Raswash Äegypten: Paleontogr. Stuttgart, Abt. A, 123: 111136.
Boltenhagen, E. 1980. Palynology of the Upper Cretaceous of Gabon. Comite Des Travaux Historiques et Scientifiqiues. Mem Sect Sci. 7: 1-191.

Bosworth, W., Mcclay, K., 2001. Structural and stratigraphic evolution of the Gulf of Suez rift, Egypt: a synthesis. Mémoires du Muséum national d'histoire naturelle (1993) 186: 567-606.

Boukhary, M., EI Nahas, S., EI-Naby, A., Aal, M.H.A., Mahsoub, M., Faris, M., 2014. Seismic and sequence stratigraphy of Upper Cretaceous-Tertiary succession, eastern Abu-Gharadig Basin, Western Desert, Egypt. Stratigraphy. 11: 109-141.

Brenac, P., Richards, K., 1996. Pediastrum as a guide fossil in sequence stratigraphy In: Good man, D. K. and Clarke, R. T., Eds.,Proceed ings of the IX International Palynological Congress, Houston, Texas, U. S. A., 1996, 239-241. College Station, TX: - American association of stratigraphic palynologists foundation

Bujak, J.P., Williams, G.L., 1978. Cretaceous palynostratigraphy of offshore southeastern Canada. Geological Survey Canada Bulletin 297, 19.

Clarke, R.F.A., Verdier, J.P., 1967. An investigation of microplankton assemblages from the Chalk of the Isle of Wight, England. 24: 1-96.

Cookson, I. 1956. Additional microplankton from Australian Late Mesozoic and Tertiary sediments. Australian Journal of Marine and Freshwater Research 7: 183191.

De Vernal, A., Giroux, L., 1991. Distribution of organic walled microfossils in recent sediments from the Estuary and Gulf of St. Lawrence: some aspects of the organic matter fluxes. Canadian Journal 
of Fisheries and Aquatic Sciences 113, 189-199.

Deaf, A., Harding, I., Marshall, J., 2014. Cretaceous (Albian-? early Santonian) palynology and stratigraphy of the Abu Tunis $1 \mathrm{x}$ borehole, northern Western Desert, Egypt. Palynology 38: 51-77.

El-Soughier, M., Deaf, A., Mahmoud, M., 2013. Palynostratigraphy and palaeoenvironmental significance of the Cretaceous palynomorphs in the Qattara Rim-1X well, North Western Desert, Egypt. Arabian Journal of Geosciences 7: 3051-3068.

El Beialy, S., El Atfy, H., Zavada, M., El Khoriby, E., Abu-Zied, R., 2010. Palynological, palynofacies, paleoenvironmental and organic geochemical studies on the Upper Cretaceous succession of the GPTSW-7 well, North Western Desert, Egypt. Marine and Petroleum Geology 27: 370385.

El Diasty, W., El Beialy, S., Abo Ghonaim, A.A., Mostafa, A., El Atfy, H., 2014. Palynology, palynofacies and petroleum potential of the Upper CretaceousEocene Matulla, Brown Limestone and Thebes formations, Belayim oilfields, central Gulf of Suez, Egypt. JAfES 95:155-167.

El Diasty, W., El Beialy, S., Mostafa, A., El Adl, H., Batten, D., 2017. Hydrocarbon source rock potential in the southwestern Gulf of Suez graben: Insights from organic geochemistry and palynofacies studies on well samples from the Ras El Bahar Oilfield. Marine and Petroleum Geology 80: 133-153.

Farouk, S., 2015. Upper Cretaceous sequence stratigraphy of the Galala Plateaux, western side of the Gulf of Suez, Egypt. Marine and Petroleum Geology 60: 136158.
Foucher, J., 1979. Distribution stratigraphique des kystes de dinoflagellés et des acritarches dans le Crétacé Supérieur du Bassin de Paris et de l'Europe septentrionale. Palaeontographica Abteilung B, 78-105.

Foucher, J., Pons, D., Mami, L., Bellier, J., 1994. Premier inventaire de la microflore crétacée (dinokystes, spores et pollen) du Sud-Est constantinois (Algérie): conséquences biostratigraphiques. Comptes rendus de l'Académie des sciences. Série 2. Sciences de la terre et des planètes 318: 1563-1570.

G.P.C, 2014. Bakr - Amer and Al Hamd integrated reservoir simulation study, internal report.

Ghorab, M., 1961. Abnormal stratigraphic features in Ras Gharib oil field, 3rd Arab Petrol. Cong. Alexandria II.

Hataba, H., Ammar, G., 1990. Comparative stratigraphic study on the Upper Cenomanian-lower Senonian sediments between the Gulf of Suez and Western Desert, Egypt, EGPC 10th Exploration and Prododuction Conference, Cairo, pp. 1-16.

Ibrahim, M., 1996. Aptian-Turonian palynology of the Ghazalat-1 well (GTX1), Qattara depression, Egypt. Review of Palaeobotany and Palynology 94: 137168.

Ibrahim, M., Abdel-Kireem, M., 1997. Late Cretaceous palynofloras and foraminifera from Ain El-Wadi area, Farafra Oasis, Egypt. Cretaceous Research 18: 633-660.

Ibrahim, M., Dilcher, D., Kholeif, S., 2009. Palynomorph succession and paleoenvironment in the upper cretaceous Abu Gharadig oil field, northwestern desert, Egypt. Micropaleontology 55: 525-558. 
Ibrahim, M., Tahoun, S.S., Zobaa, M.K., Oboh-Ikuenobe, F.E., Kholeif, S.E., 2020. Late cretaceous palynology and paleoenvironment of the razzak-3 well, north Western Desert, Egypt. Arabian Journal of Geosciences 13: 1-23.

Helby, R., Morgan, R., Partridge, A., 1987. A palynological zonation of the Australian Mesozoic. Memoir of the Association of Australasian Palaeontologists 4: 1-94.

Ied, I., Tahoun, S., 2018. A Cretaceous sporomorph palynozonation and the palaeobiogeography of northern Egypt. Palynology 43: 467- 482.

Kerdany, M., Cherif, O., 1990. Mesozoic, in: Said, R. (Ed.), The geology of Egypt. Balkema, pp. 407-438.

Lawal, O., Moullade, M., 1986. Palynological biostratigraphy of Cretaceous sediments in the upper Benue Basin, NE Nigeria. Rev. Micropaleontol. 29: 61-83.

Lebedeva, N., 2006. Dinocyst biostratigraphy of the Upper Cretaceous of northern Siberia. Paleontological Journal 40: S604-S621.

Macphail, M.K., Truswell, E.M., 2004. Palynology of Neogene slope and rise deposits from ODP Sites, 1165 and, 1167, East Antarctica. In: Cooper, A.K., O’Brien, P.E., Richter, C. (Eds.) Proceedings of the Ocean Drilling Program, Scientific Results, 188, College Station, Texas, , 1-20.

Mahmoud, M., 2003. Palynology and palaeoenvironment of the Quseir Formation (Campanian) from central Egypt. Journal of African Earth Sciences 36: $135-148$.

Mandur, M., Baioumi, A., 2009. Stratigraphical and paleoecological studies on Upper Cretaceous succession of Gs 160-2 well, Gulf of Suez, Egypt.
Journal of Applied Sciences Research 5: 2247-2261.

Mousa, A., El Hariri, T., Abu El-Ezz, A., 2011. A study of microfacies and petrophysical analysis of some subsurface Cretaceous rocks of Abu Gharadig-34 Well, Western Desert, Egypt. . Petroleum Science Technology 29: 2306-2320.

Nøhr-Hansen, H., 1996. Upper Cretaceous dinoflagellate cyst stratigraphy, onshore West Greenland. Grønlands Geologiske Undersøgelse, Bulletin 170, 103.

Nøhr-Hansen, H., 2012. Palynostratigraphy of the Cretaceous-lower Palaeogene sedimentary succession in the Kangerlussuaq Basin, southern East Greenland. . Review of Palaeobotany and Palynology 178: 59-90.

Nøhr-Hansen, H., Piasecki, S., Alsen, P., (online), 2019 (Online). A Cretaceous dinoflagellate cyst zonation for $\mathrm{NE}$ Greenland Geological Magazine https://doi.org/10.1017/ S0016756819001043.

Pearce, M.A., Jarvis, I., Ball, P.J., Laurin, J., 2020. Palynology of the Cenomanian to lowermost Campanian (Upper Cretaceous) Chalk of the Trunch Borehole (Norfolk, UK) and a new dinoflagellate cyst bioevent stratigraphy for NW Europe. Review of Palaeobotany and Palynology 278: 104188.

Prince, I., Jarvis, I., Pearce, M., Tocher, B., 2008. Dinoflagellate cyst biostratigraphy of the Coniacian-Santonian (Upper Cretaceous): new data from the English Chalk. Review of Palaeobotany and Palynology 150: 59-96.

Ravn, R., 1998. TAXON: a DOS hypertext database of 30,000 species of palynomorphs with references and annotations. 
Riding, J., Crame, J., 2002. Aptian to Coniacian (Early-Late Cretaceous) palynostratigraphy of the Gustav Group, James Ross Basin, Antarctica. . Cretaceous Research 23:739-760.

Robaszynski, F., Foucher, J., Gaspard, D., Magniez-Jannin, F., Manivit H., 1980. Synthèse biostratigraphique de l'Aptien au Santonien du Boulonnais à partir de sept groupes paléontologiques: Foraminifères, Nannoplancton, Dinoflagellés et Macrofaunes. Zonations micropaléontologiques intégrées dans le cadre du Crétacé boréal nord-européen. . Revue de Micropaleontologie, 22: 195321.

Said, R., Kenawy, A., 1957. Foraminifera from the Turonian rocks of Abu Roash Egypt. . Contributions from the Cushman Foundation for Foraminiferal Research 8: 7786.

Schioler, P., Wilson, G.J., 1998. Dinoflagellate biostratigraphy of the middle Coniacian-lower Campanian (Upper Cretaceous) in south Marlborough, New Zealand. Micropaleontology 44: 313-349.

Schrank, E., Ibrahim, M., 1995. Cretaceous (Aptian-Maastrichtian) palynology of foraminifera-dated wells (KRM-1, AG18) in northwestern Egypt. Selbstverlag Fachbereich Geowissenschaften, FU Berlin.

Soliman, A., 2012. Oligocene dinoflagellate cysts from the North Alpine Foreland Basin: new data from the Eggerding Formation (Austria). Geologica Carpathica 63: 49-70.

Srivastava, S., 1992. Dinocyst biostratigraphy of Cenomanian-Coniacian formations of the western Gulf Coastal Plain, southern United States. Palaeobotanist 39: 155235.
Sultan, I., Aly, S., Arafa, A., 1986. Palynostratigraphy of the TuronianLower Senonian sequence, Gulf of Suez Area, Egypt. Bulletin of Faculty of Science, Alexandria University 26: 1-17.

Sweet, A., McIntyre, D., 1988. Late Turonian marine and nonmarine palynomorphs from the Cardium Formation, northcentral Alberta Foothills, Canada. Canadian Society of petroleum Geologists 15: 499-516.

Tahoun, S., Deaf, A., Mansour, A., 2017. Palynological, palaeoenvironmental and sequence stratigraphical analyses of a Turonian-Coniacian sequence, Beni Suef Basin, Eastern Desert, Egypt: Implication of Pediastrum rhythmic signature. Marine and Petroleum Geology 88: 871-887

Williams, G.L., Brideaux, W.W., , 1975. Palynologic analyses of Upper Mesozoic and Cenozoic rocks of the Grand Banks, Atlantic Continental Margin, Geological Survey of Canada Bulletin 236: 1-162.

Williams, G.L., Bujak, J.P., 1985. Mesozoic and Cenozoic dinoflagellates; in Bolli, H. M. (ed), Planktonic Stratigraphy. Cambridge University Press, Cambridge, 847- 964.

Wiliams , G.L., Stover, L.E., Kidson, E.J., 1993. Morphology and stratigraphic ranges of selected Mesozoic - Cenozoic dinoflagellate taxa in the Northern Hemisphere. Geolgical Survy Canada Paper 92: 1-37.

Williams, G., Brinkhuis, H., Pearce, M., Fensome, R., Weegink, J., 2004. Southern Ocean and global dinoflagellate cyst events compared: index events for the Late Cretaceous-Neogene. Proceedings of the Ocean Drilling Program, Scientific Results 189: 1-98.

Wood, G., Gabriel , A., Lawson , J., 1996. Palynological techniques-processing and 
microscopy. Palynology: Principles and applications. American Association of Stratigraphic Foundations, Dallas 1: 2950 .

Young, M., Gawthorpe, R., Sharp, I., 2000. Sedimentology and sequence stratigraphy of a transfer zone coarse- grained delta, Miocene Suez Rift, Egypt. Sedimentology 47: 1081-1104.

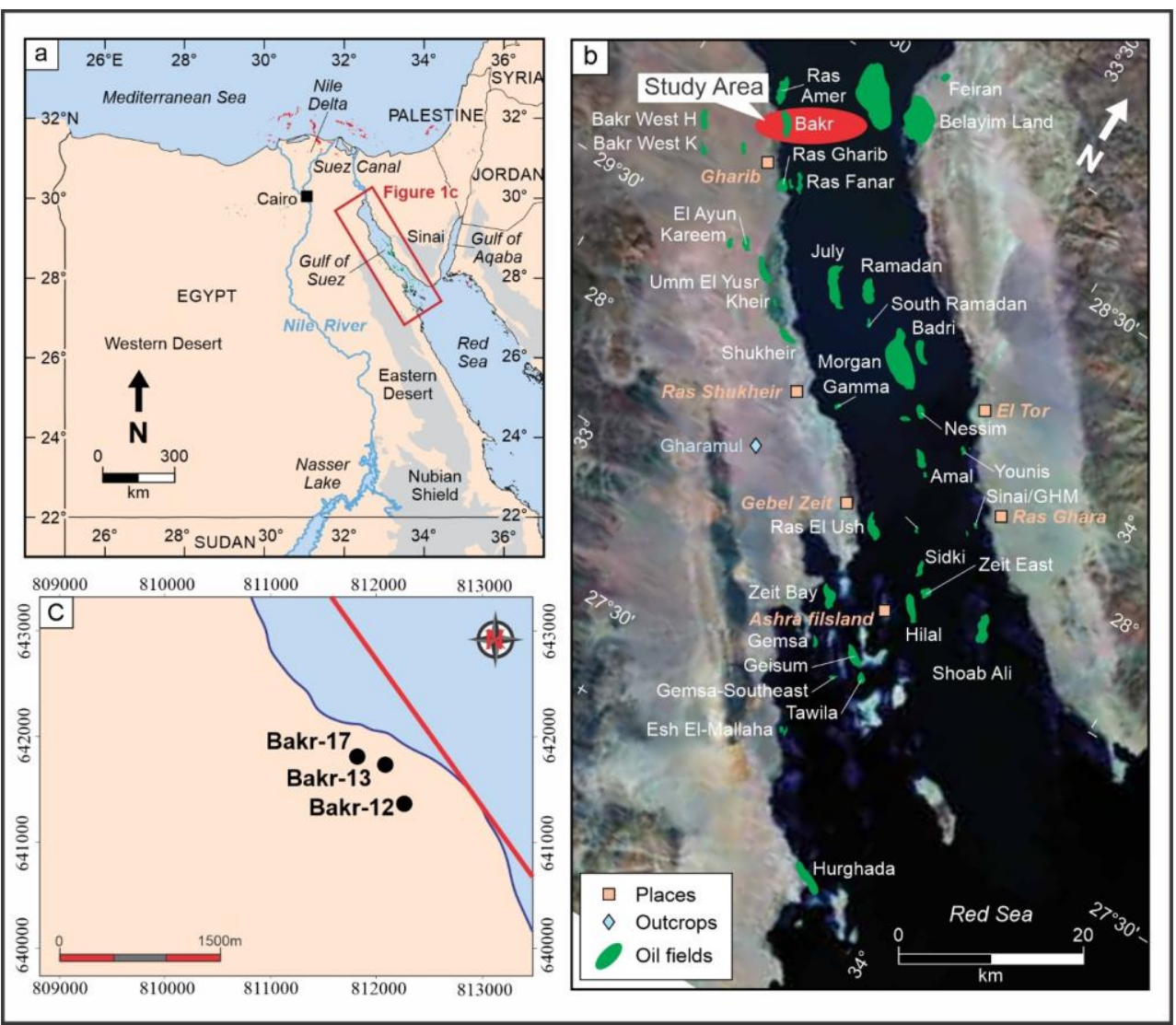

Fig. (1a, 1b): Generalized Concession map of different oil fields in the area of Gulf of Suez) and locations of the studied three wells Bakr 12, 13, and 17 (c). 


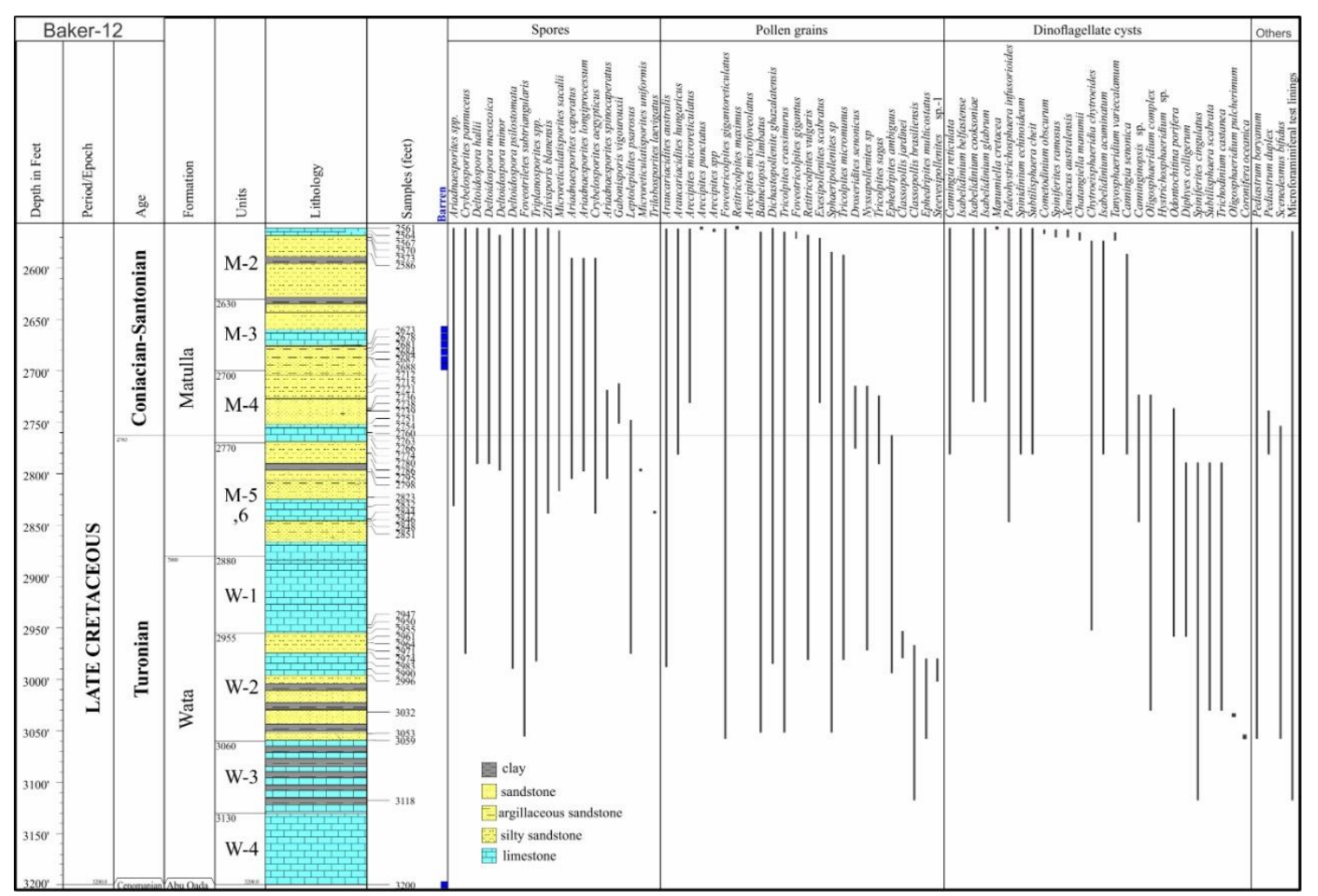

Fig. (2): Palynostratigraphic range chart (spores, pollen, and dinoflagellate), Well Bakr- 12.

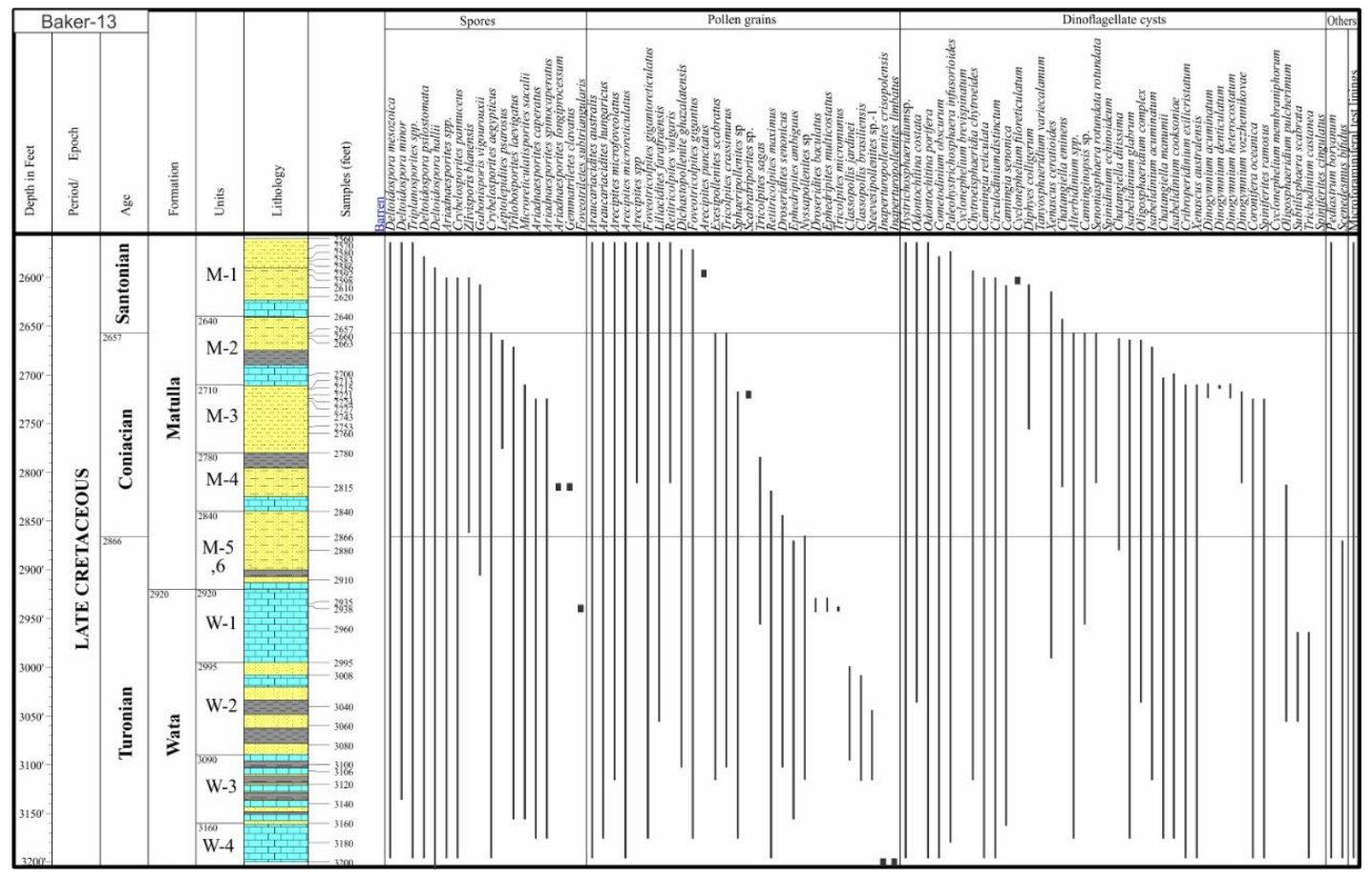

Fig. (3): Palynostratigraphic range chart (spores, pollen, and dinoflagellate), Well Bakr- 13. 


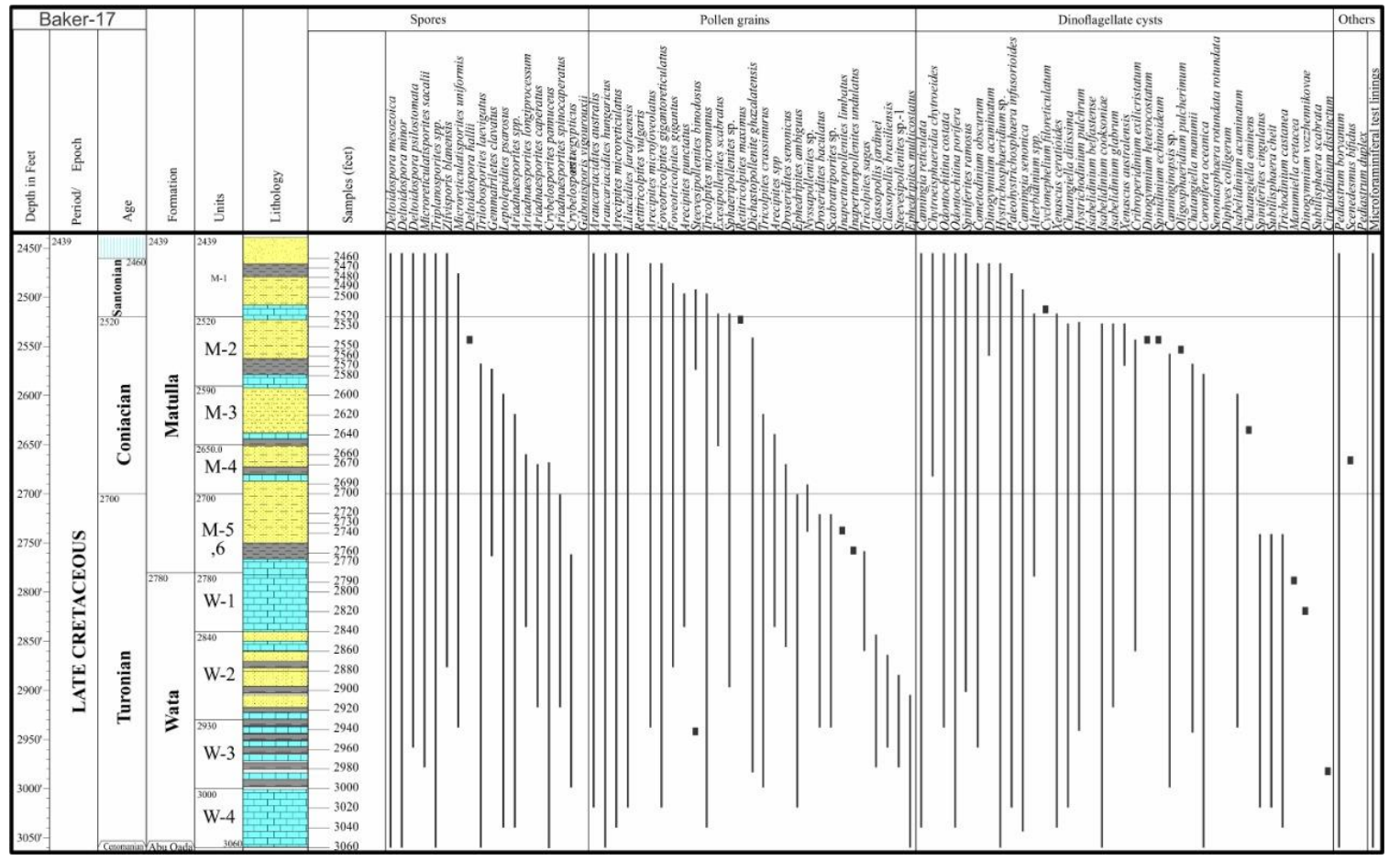

Fig. (4): Palynostratigraphic range chart (spores, pollen, and dinoflagellate), Well Bakr- 17. 


\section{Plate-1}
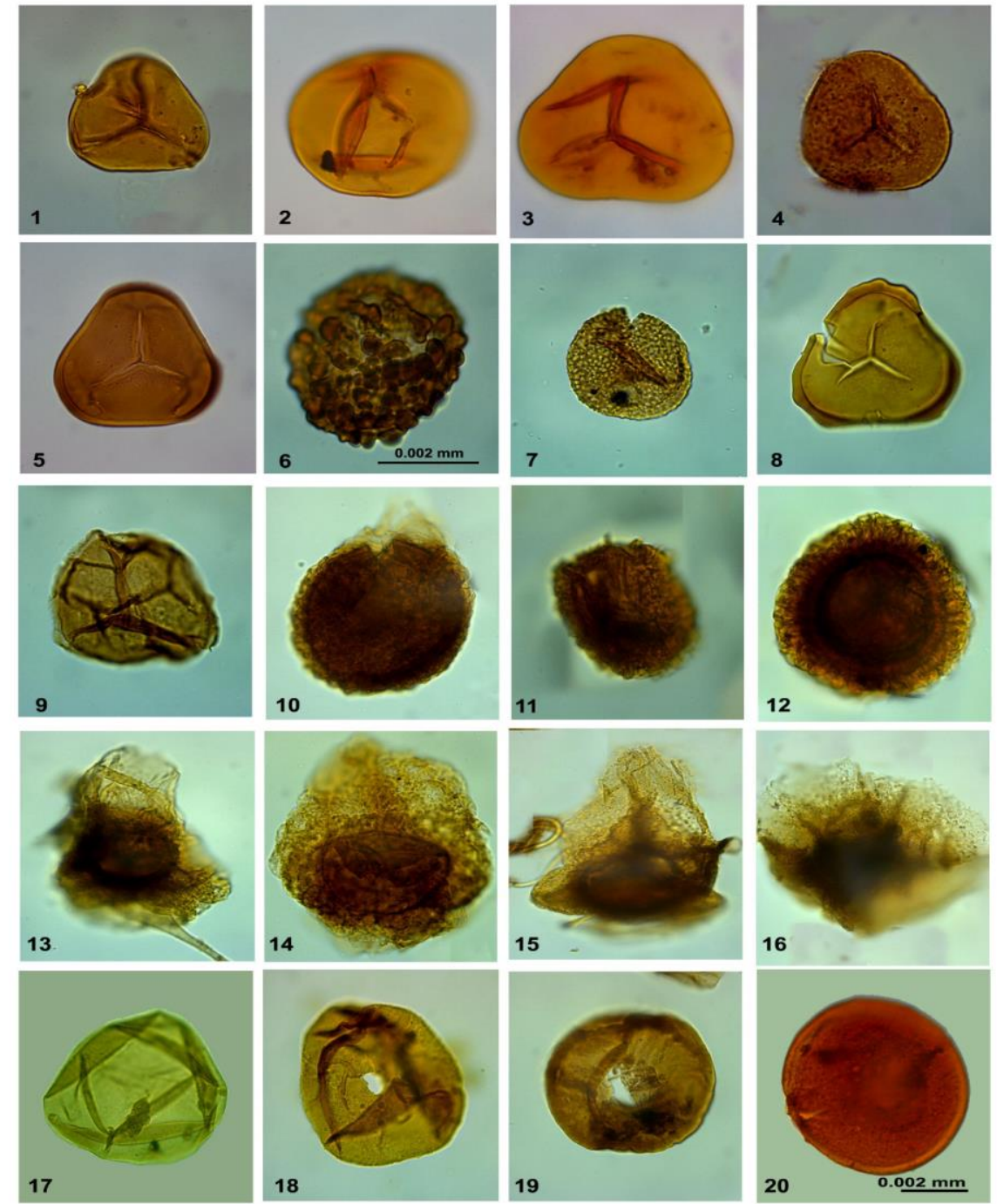

1. Biretisporites potoniaei Delcourt \& Sprumont 1955, B-12, depth 2971- 2974, V 28/4.

2. Deltoidospora hallii Miner, 1935, B-12, depth 2766-2786, A23/4.

3. Deltoidospora mesozoica (Thiergart) Schuurman, 1977, B-12, depth 2766-2786, R12/3.

4. Deltoidospora psilostoma; Rouse 1959, B-12, depth 2980-2983, E 26/1.

5. Dictyophyllidites sp., B-12, depth 2718-2721, T43/4.

6. Leptolepidites psarosus Norris 1969, B-12, depth 2841-2844, J28.

7. Foveotriletes subtriangularis Kedves. 1997, B-12, depth 2980-2983, G15/1.

8. Trilobosporites laevigatus, El Beialy 1994a, B-17, depth 2570-2580, V40/3.

9. Zlivisporis blanensis Pacltova, 1961, B-12, depth 2841-2844, W 33/3.

10. Crybelosporites pannuceus (Brenner) Srivastava,1977, B-12, depth 2718-2721, T12/2.

11. Crybelosporites aegypticus, Kedves 1995, B-12, depth 2841-2844, Y28/2.

12. Gabonisporis vigourouxii Boltenhagen 1967, B-12, depth 2751-2754, D27/1.

13. Ariadnaesporites longiprocessum (Hills \& Jensen) Hills 1967, B-12, depth 2718-2721, B13.

14. Ariadnaesporites caperatus Singh, 1983, B-12; depth 2570-2573; U48.

15. Ariadnaesporites spinocaperatus Phillips \& Felix 1971, B-12, depth 2718-2721, W14.

16. Ariadnaesporites spp., B-17, depth 2710-2720, F8/4.

17. Araucariacites australis Cookson ex Couper 1953, B-12, depth 2570-2573, V32

18. Araucariacites hungaricus Deak, 1964, B-12, depth 2558-2561, J28/1.

19. Balmeiopsis limbata (Balme) Archangelsky 1979, B-12, depth 2570-2573, Q44/1.

20. Exesipollenites scabratus, Balme 1957, B-12, depth 2567-2570, Q21/3. 


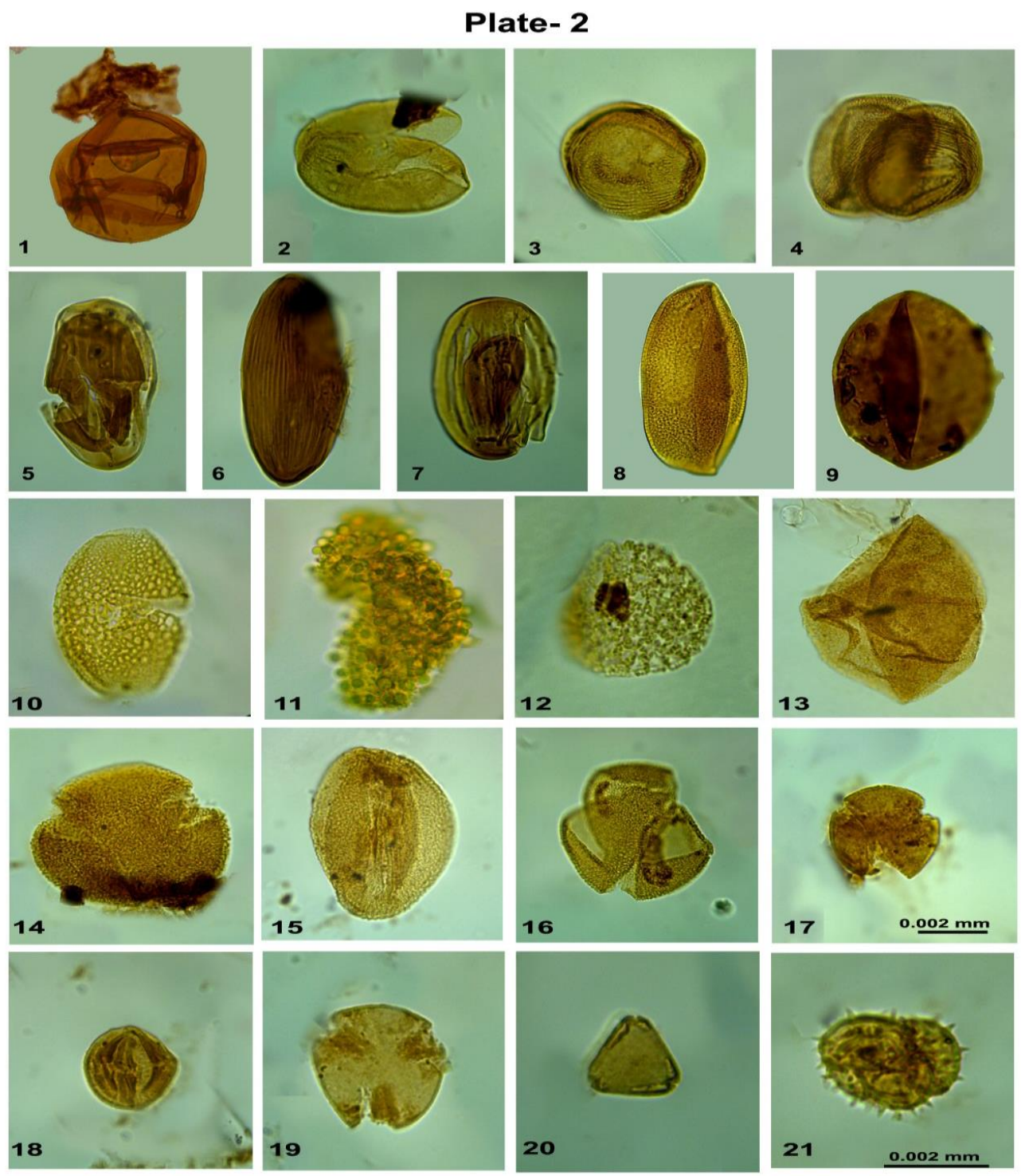

1. Sphaeropollenites sp., B-17, depth 2570-2580-G48/2.

2. Classopollis brasiliensis Herngreen 1975, B-17, depth 2850-2860, R10.

3. Classopollis jardinei Herngreen 1973, B-17, depth 2850-2860, U23.

4. Diod of Classopollis jardinei, Herngreen 1973, B-17, depth 2930-2940, Y32.

5. $\quad$ Ephedripites ambiguus Hedlund 1966, B-12, depth 2980-2983, D52/4.

6. $\quad$ Ephedripites multicostatus Brenner 1963, B-12, depth 2971-2974, W8/1.

7. Steevisipollenites sp- 1, B-12, depth 2980-2983, C22.

8. Arecipites microfoveolatus Ibrahim, 2002, B-12, depth 2570-2573, L27/2.

9. Retimonocolpites spp., B-13, depth 2813-2815, D-19.

10. Liliacidites farafraensis, Ibrahim \& Abdel El Kireem, 1997, B-17, depth 2470-2480, F31/1.

11. Stellatopollis sp., B-13, depth 2718-2721, Q15/2.

12. Dichastopollenites ghazalatensis Ibrahim 1996, B-13, depth 2813-2815, M43/1.

13. Foveotricolpites gigantus (Jardiné \& Magloire) Jan du Chêne et al. 1978, B-13, depth 2813 2815, W49/2.

14. Foveotricolpites gigantoreticulatus (Jardiné \& Magloire) Schrank 1987b, B-17, depth 27602770, G27/3.

15. Retitricolpites Vulgaris (Pierce) Srivastava, 1969, B-17, depth 2690-2700, D26.

16. Tricolpites crassimurus (Groot and penny), Singh, 1971, B-17, depth 2930-2940, G34/4.

17. Tricolpites sagas Norris, 1967, B-17, depth 2750-2760, J39/2.

18. Retitricolporites sp., B-17, depth 2690-2700, W38/2.

19. Nyssapollenites sp., Thiergart 1937, B-17, depth 2760-2770, R44.

20. Scabratriporites sp., B-17, depth 2710-2720, O29/2.

21. Droseridites senonicus Jardiné \& Magloire 1965, B-17, depth 2690-2700, S46/2 


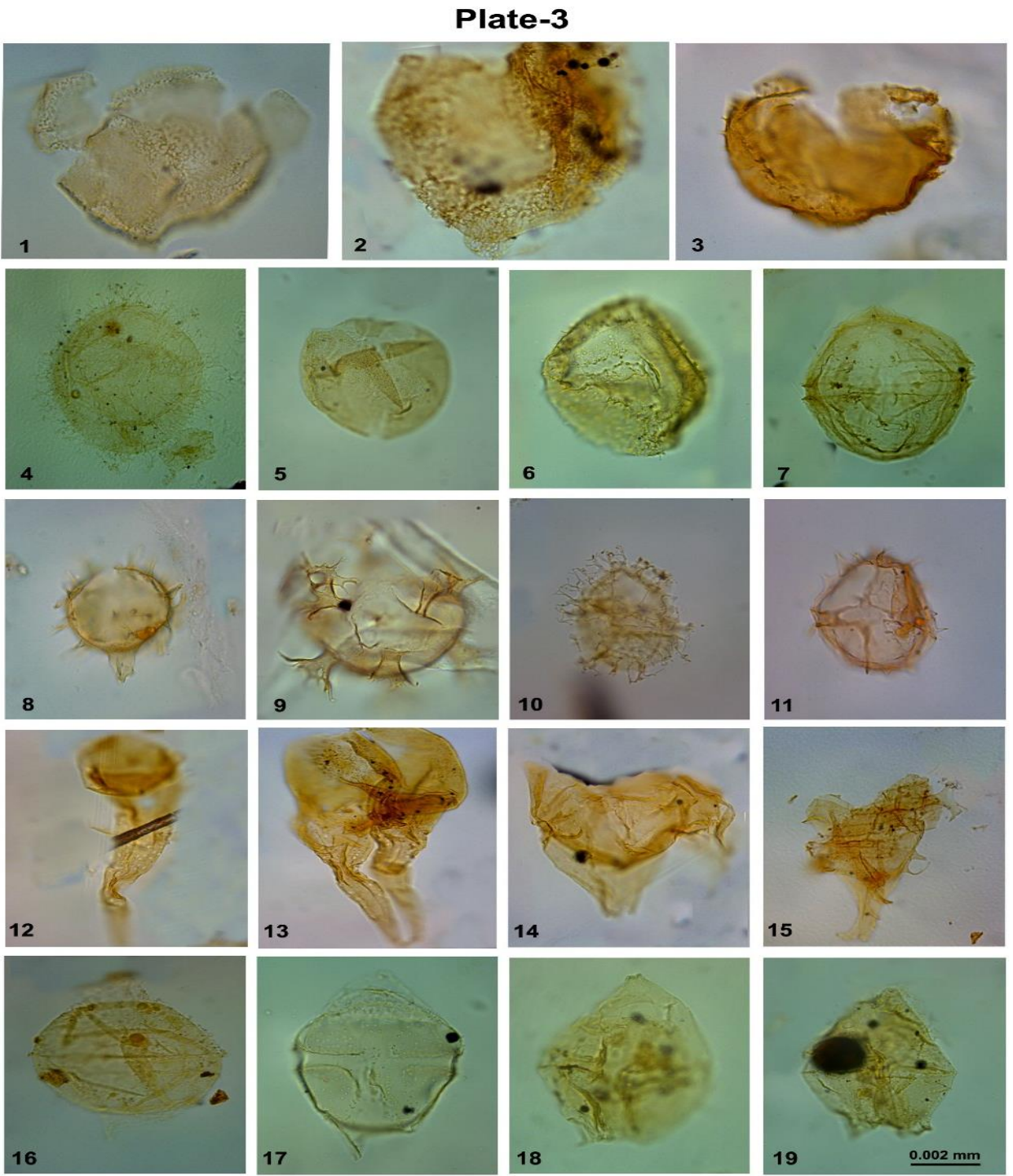

1. Canningia reticulata Cookson and Eisenack, 1960; emend. Below, 1981; emend. Helby, 1987, B-12, depth 2766-2786, D27.

2. Canningia senonica Clarke \& Verdier 1967, B-13, depth 2813-2815, W30/2.

3. Canninginopsis sp. Cookson and Eisenack, 1962, B-12, depth 2850-2851, E35/1.

4. Cometodinium obscurum Deflandre and Courteville, 1939 emend. Monteil, 1991, B-13, depth 2813-2815, Q40.

5. Sentusidinium spp., B-17, depth 2657-2670, N42/2.

6. Trichodinium castanea; Deflandre 1935 ex Clark and Verdier 1967, B-12, depth 2969-2971, N19/1.

7. Cribroperidinium exilicristatum (Davey, 1969) Stover and Evitt, 1978, B-17, depth 2850-2860, Q13/4.

8. Diphyes colligerum (Deflandre and Cookson, 1955) emend. Goodman and Witmer, 1985, B-12, depth 2766-2786, Z16.

9. Oligosphaeridium pulcherrimum (Deflandre and Cookson, 1955) Davey and Williams, 1966, B-12, depth 3029-3032, L47.

10. Spiniferites ramosus (Ehrenberg) Loeblich \& Loeblich 1966, B-12, depth 2567-2570, B20.

11. Spiniferites cingulate, B-12, depth 2766-2786, D47.

12. Odontochitina porifera Cookson 1956, B-17, depth 2470-2480, S33/4.

13. Odontochitina costata Clarke and Verdier, 1967, B-17, depth 2450-2460, J9/3.

14. Xenascus australensis Cookson and Eisenack, 1969, B-13, 3190-3200, J31-2.

15. Xenascus ceratioides (Deflandre, 1937) Lentin and Williams, 1973, B-13, depth 3718-2721, E45/3.

16. Palaeohystrichophora infusorioides Deflandre 1935, B-12, 2567-2570, Y24/3.

17. Subtilisphaera scabrata Jain and Millepied, 1973, B-12; 3029-3032; F44/3.

18. Alterbidinium spp., B-13, 2813-2815, J51/1.

19. Chatangiella ditissima Lentin and Williams, 1976, B-17, 2657-2670, C8/3. 


\section{Plate- 4}
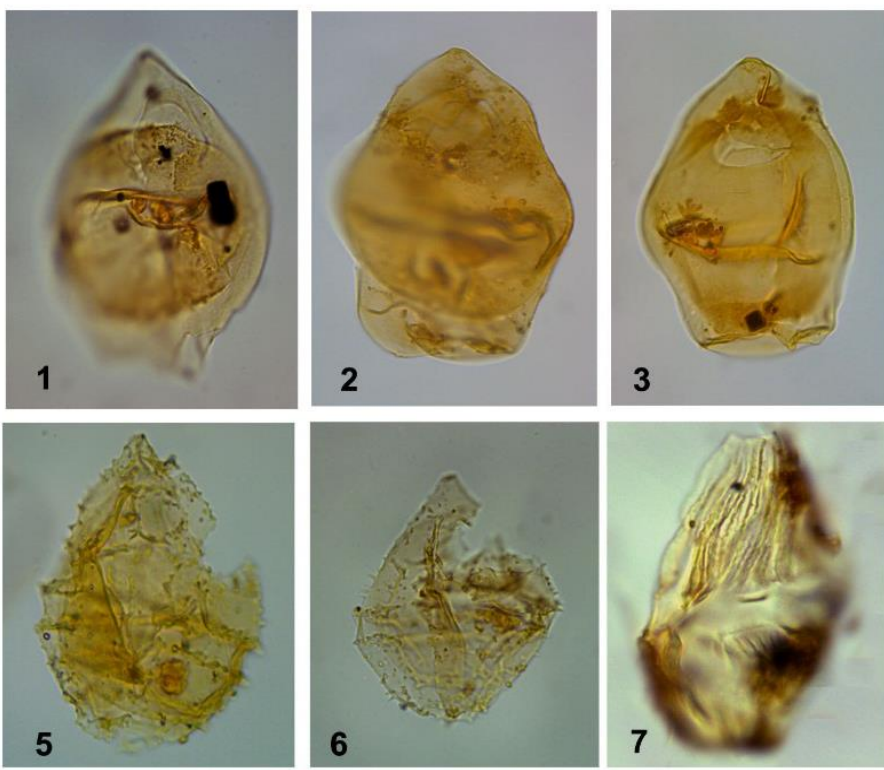

4
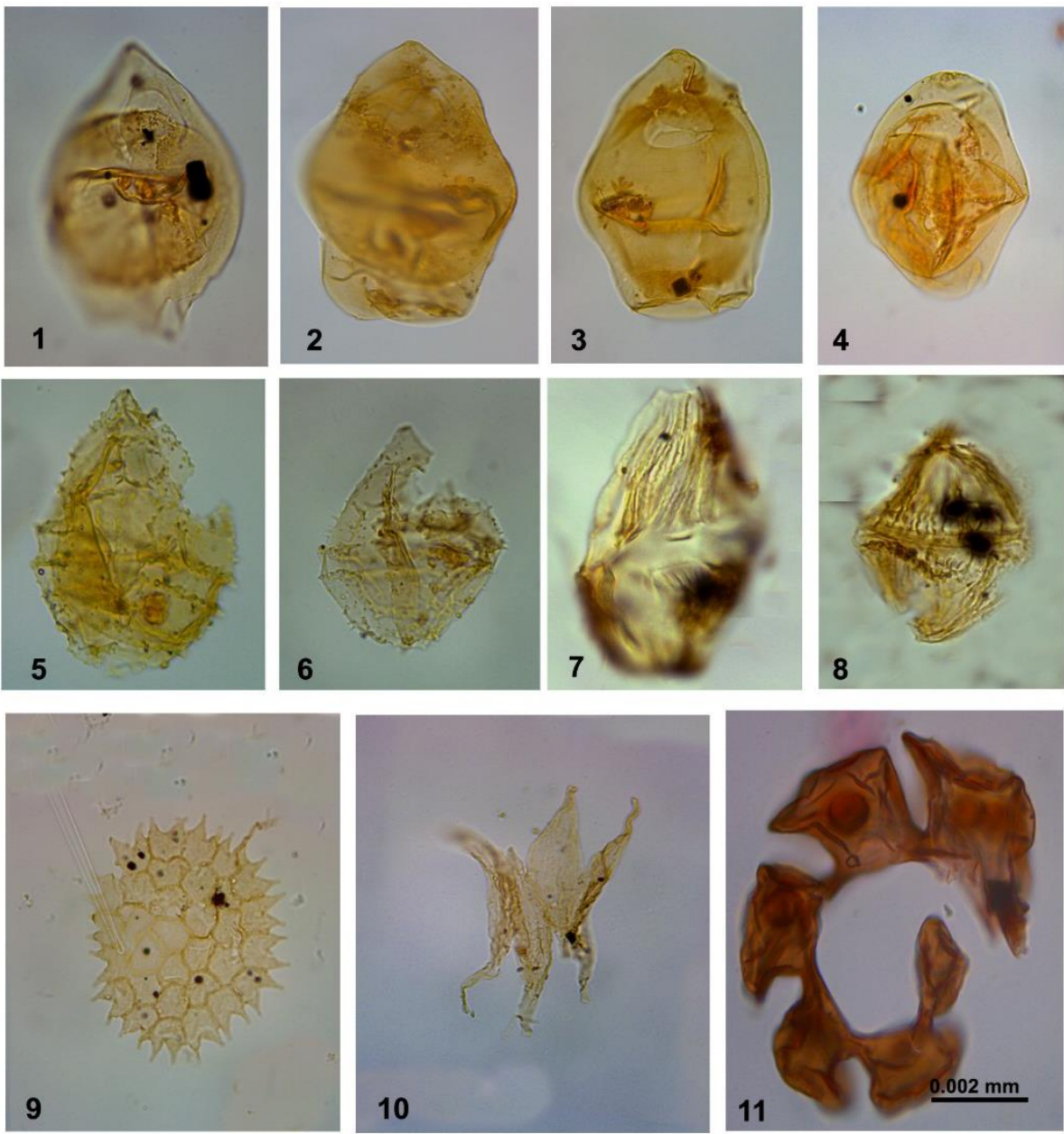

1. Isabelidinium acuminatum (Cookson and Eisenack, 1958) Stover and Evitt, 1978, B-12, 2570-2573, J8.

2. Isabelidinium cooksoniae (Alberti, 1959) Lentin and Williams, 1977, B12, 2567-2570, E20.

3. Isabelidinium glabrum; (Cookson and Eisenack 1969) Lentin and Williams 1977, B-12, 2558-2561, A49.

4. Manumiella cretacea (Cookson, 1956) Bujak and Davies, 1983, B-12, 2558-2561, P32.

5, 6. Spinidinium echinodeum (Cookson and Eisenack, 1960; emend. Sverdlove and Habib, 1974) Lentin and Williams, 1976.

5. B-12, depth 2564-2567, L7. 6. B-12, depth 2564-2567, L27/1.

7. Dinogymnium heterocostatum subsp. Kolpaschevii (Vozzhennikova) emend. Lentin \& Williams 1973, B-13, depth 2713-2715, K32/2.

8. Dinogymnium vozzhennikovae, Lentin and Williams, 1973 emend. Lentin and Vozzhennikova, 1990, B-13, depth 2713-2715, G31/3.

9. Pediastrum boryanum (Turpin) Meneghini 1840, B-17, depth 2510-2520, U38/4.

10. Scenedesmus bifidus Batten \& lister 1988, B-12, depth 2795-2798, F61.

11. Microforaminiferal inner test lining, B12, depth 2766-2786- G23 
دراسات بالينولوجية على العصر الطباثيرى العلوى لمتكونى الواطة والمطلة فى جلى

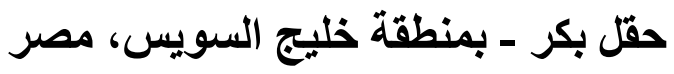

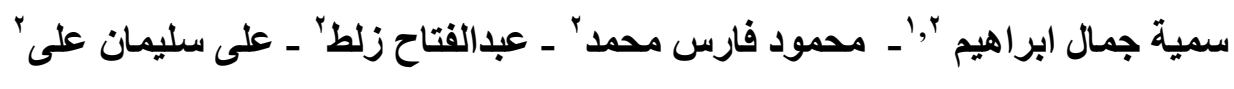

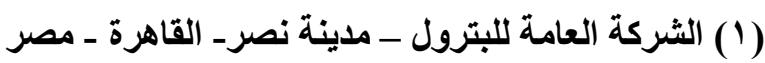

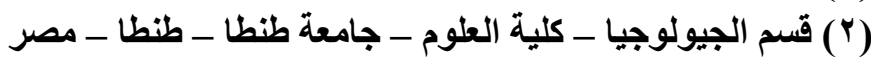

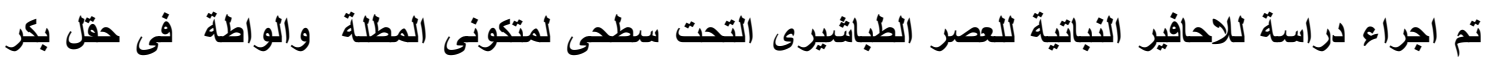

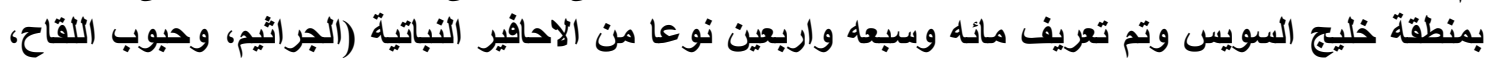
والسوطيات، والطحالب الخضر اءع) وتهرئ. تم تحديد عمر تلك الصخور بناءا على تواجد أنواع هامة من الناحية الاستراتيجرافية مثل:

Liliacidites farafraensis, Droseridites senonicus, Ephedripites ambiguus, Isabelidinium cooksoniae, Isabelidinium glabrum, Odontochitina porifera, Odontochitina costata, and Trichodinium castanea

$$
\text { والتى تلال على العمر الترونى والساتتونى. }
$$

تم القاء الضوء على البيئات الترسيبية لمتكون الواطة بمنطقة الدراسة والذى تم ترسيبه اثناء تقلم البحر

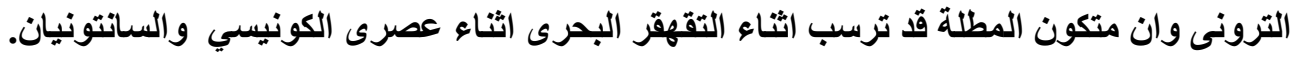

ان تواجد بعض مجموعات حبوب اللقاح مصاحبة لبعض انواع من الجراثيم تثير الى اجواء استوائية رطبة. كما

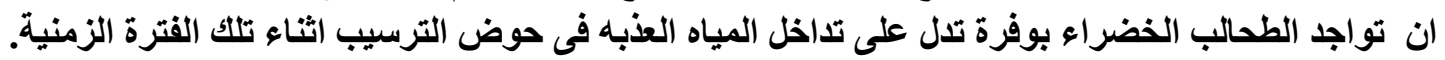

